\title{
Turystyka zrównoważona na obszarach przyrodniczo cennych: strategie i implementacja
}

\author{
Piotr Majdak \\ Akademia Wychowania Fizycznego J. Piłsudskiego w Warszawie \\ ul. Marymoncka 34, 00-968 Warszawa \\ piotr.majdak@awf.edu.pl
}

\section{Streszczenie}

Przedstawione w artykule rozważania ogniskują się wokół zagadnień związanych z implementacją założeń koncepcji rozwoju zrównoważonego w odniesieniu do obszarów przyrodniczo cennych, pełniących funkcje turystyczne. W kręgu zainteresowań badawczych znalazły się dwa kraje: Finlandia oraz Stany Zjednoczone Ameryki Północnej. Ze względu na dużą różnorodność wynikającą zarówno z uwarunkowań przyrodniczych, geograficznych, przestrzennych jak i organizacyjnych czy politycznych - prezentowany katalog rozwiązań praktycznych zawiera obszerny zestaw inicjatyw, które realizują w praktyce założenia rozwoju zrównoważonego. Wśród nich wymienić można zarówno działania wynikające z realizacji ogólnonarodowych projektów jak i inicjatywy realizowane na poziomie stowarzyszeń lokalnych.

Prezentowane rozwiązania uwidaczniają, że założenia rozwoju zrównoważonego stanowią źródło cennych inspiracji dla działań praktycznych, a sama koncepcja nie ogranicza się jedynie do warstwy dyskursywnej i teoretycznej.

\section{Słowa kluczowe}

turystyka zrównoważona, obszary przyrodniczo cenne

\section{Wprowadzenie}

Walory i zasoby przyrodnicze uznawane są za jedne z podstawowych czynników decydujących o atrakcyjności turystycznej danego obszaru. Dotyczy to nie tylko terenów objętych ochroną na mocy prawa (takich jak np. rezerwaty czy parki narodowe), ale także obszarów przyrodniczo cennych, definiowanych jako te, których wartości (...) stużyć moga zaspokojeniu potrzeb wypoczynkowych, turystycznych, zdrowotnych, kulturalnych, estetycznych, naukowych i innych (Jalinik
2009: 88), pozostających poza oficjalnym systemem ochrony.

W tym kontekście dostrzec można bardzo istotny paradoks: obszary o cennych wartościach środowiskowych, ze względu na niezdegradowane walory powinny podlegać ochronie, z drugiej jednak strony służyć mają zaspokajaniu rozmaitych potrzeb społecznych, gospodarczych, kulturowych i innych. Rodzące się na tym tle konflikty wymagają podejmowania kompleksowych i dalekowzrocznych decyzji, uwzględniających 
jednocześnie postulaty i oczekiwania różnych grup interesu (Kowalczyk 2010: 33).

Prezentowane w dalszej części artykułu rozważania wskazują na istotne znaczenie koncepcji turystyki zrównoważonej, która postuluje - w dużym uproszczeniu - koniczność poszukiwania kompromisów pomiędzy wszystkimi podmiotami występującymi na danym obszarze oraz takie projektowanie rozwoju, które uwzględniać będzie daleki horyzont czasowy (Kassenberg 2007: 54).

Przedstawiane w dalszej części artykułu wyniki badań własnych, ze względu na wieloaspektowość poruszanych zagadnień, odwołują się do rożnych źródeł danych i informacji. Wśród najważniejszych wymienić można następujące:

- literaturę podmiotu oraz dokumenty i opracowania dostępne m.in. na oficjalnych stronach internetowych poświęconych obszarom chronionym wybranych krajów oraz materiały informacyjne dostępnych w parkach narodowych (analiza danych zastanych),

- informacje uzyskane w trakcie rozmów prowadzonych $\mathrm{z}$ pracownikami parków narodowych (wywiady swobodne z elementami wywiadu pogłębionego),

- obserwację uczestniczącą,

- analizy komparatystyczne.

Prezentowane wyniki badań odnoszą się do dwóch krajów:

- Finlandii - będącej krajem o stosunkowo niewielkiej powierzchni, natomiast posiadającej obszerny katalog chronionych form. Jednocześnie Finlandia uznawana jest za kraj bardzo innowacyjny, także w odniesieniu do sposobów zarządzania środowiskiem przyrodniczym,

- Stanów Zjednoczonych Ameryki Północnej - posiadających rozbudowany system ochrony przyrody oraz obszary przyrodniczo cenne, które należą do najliczniej odwiedzanych na świecie.
Ze względu na dużą różnorodność wynikającą zarówno z uwarunkowań przyrodniczych, geograficznych, przestrzennych jak i organizacyjnych czy politycznych wymienionych krajów - prezentowany w dalszej części katalog rozwiązań praktycznych zawiera obszerny zestaw działań, które realizują w praktyce założenia rozwoju zrównoważonego. Wśród nich wymienić można zarówno inicjatywy wynikające z realizacji ogólnonarodowych projektów jak i projekty realizowane na poziomie stowarzyszeń lokalnych. Jednocześnie należy zwrócić uwagę, że prezentowane wyniki stanowią jedynie niewielki fragment analiz i badań własnych prowadzonych w obszarze omawianych zagadnień.

\section{Strategie rozwoju zrównoważonego i implementacja}

Koncepcja rozwoju zrównoważonego stanowi istotny punkt odniesienia dla wielu programów rozwoju. Poniżej przedstawiono wybrane dokumenty, które zawierają bezpośrednie wskazania dotyczące działań praktycznych, służących implementacji założeń rozwoju zrównoważonego.

\subsection{Finlandia (Web-01, Web-02)}

Administrowanie fińskimi obszarami chronionymi pozostaje $\mathrm{w}$ gestii wyspecjalizowanego przedsiębiorstwa państwowego Metsähallitus, które odpowiada także za pozyskiwanie drewna do celów przemysłowych. Jednym z zasadniczych celów organizacji jest promowanie i organizowanie zrównoważonej turystyki na obszarach chronionych, obszarach dzikiej przyrody i terenach objętych specjalnymi programami ochrony, przy udziale rozmaitych grup interesu. Cele te zgodnie z przyjętą strategią - realizowane są m.in. poprzez:

- minimalizowanie obciążeń dla środowiska,

- promowanie i wzmacnianie lokalności,

- wspieranie i ochronę lokalnych walorów,

- promowanie aktywności służącej zdrowiu i dobremu samopoczuciu, 
- promowanie lokalnej gospodarki i tworzenie miejsc pracy.

Powyższe zasady zrównoważonej turystyki na obszarach chronionych zostały zaktualizowane w 2016 roku (pierwotna wersja została sformułowana już w roku 2004) we współpracy z instytucjami Światowego Dziedzictwa UNESCO w Finlandii i są wykorzystywane podczas działań planistycznych, w tym - na poziomie lokalnym - jako podstawa budowania strategii zrównoważonego rozwoju turystyki (wraz z określeniem przyszłych potrzeb rozwojowych). Ponadto Metsähallitus opracował zestaw wskaźników opartych na limitach dopuszczalnych zmian (zgodnie ze wzmiankowaną wcześniej filozofią LAC - Limits of Acceptable Changes), a także zaplanował działania, które zapobiegają przekraczaniu tych wskaźników.

Wśród rozmaitych działań pozwalających implementować założenia rozwoju zrównoważonego znajdują się także:

\section{Współpraca korporacyjna}

W oparciu o powyższe wskazania zrównoważonego rozwoju Metsähallitus zawiera umowy współpracy z lokalnymi firmami działającymi na obszarach chronionych, w których określa się akceptowalne i zrównoważone zasady współpracy. Porozumienia te umożliwiają z jednej strony monitorowanie działalności prywatnych spółek, z drugiej natomiast zapewniają przedstawicielom firm dostęp do najbardziej aktualnej wiedzy z zakresu zrównoważonego zarządzania, udział przy tworzeniu produktów, wspólne działania promocyjne i marketingowe.

\section{Promowanie wolontariatu}

Poza współpracą korporacyjną Metsähallitus aktywnie podnosi świadomość na temat ekosystemów. Wśród wartych odnotowania inicjatyw wymieć można chociażby promowanie przez wolontariatu połączonego z wakacjami na wolnym powietrzu (np. akcja wypasu owiec, podczas której wolontariusze mogą nauczyć się dbać o owce i jednocześnie cieszyć się krajobrazami otaczającymi gospodarstwa położone w parkach narodowych i obszarach chronionych. Jednocześnie owce utrzymują otwarte łąki i krajobrazy, dzięki czemu chroniona jest także tradycyjna flora i fauna).

Redystrybucja funduszy, tworzenie źródeł dochodu Lokalne gospodarki korzystają z funduszy przyznawanych przez fiński rząd na parki narodowe i tereny turystyczne. Oszacowano, że fundusze te wracają do społeczeństwa wielokrotnie przez lokalną przedsiębiorczość i miejsca pracy. W 2015 r. Łączna liczba wizyt w parkach narodowych, krajowych obszarach turystycznych i kilku innych chronionych obszarach rekreacyjnych wyniosła prawie 4 miliony. Tylko w 39 parkach narodowych całkowity dochód i zatrudnienie wyniosły 141,5 miliona euro i około 1400 miejsc pracy (równowartość w pełnym wymiarze godzin), a dla wszystkich 6 obszarów turystycznych - 12,2 miliona euro i około 131 miejsc pracy (w przeliczeniu na pełne etaty) 2015. Największy wpływ na gospodarkę lokalną mają centra turystyczne, w których goście przebywają dłużej, a podaż usług turystycznych jest większa (Web-o3).

Stosunek nakładów do produkcji w parkach narodowych jest również korzystny. Parki narodowe zwracają 10 euro lokalnym gospodarkom za każde euro zainwestowane przez fińskiego podatnika. Wartość świadczeń zdrowotnych, jakich doświadczyli fińscy odwiedzający parki narodowe w $2013 \mathrm{r}$. została obliczona w sprawozdaniach Metsähallitus na łączną kwotę 226 milionów euro (Web-03).

\section{Korzyści społeczne}

W 2013 r. Po raz pierwszy w Finlandii zbadano wpływ odwiedzin parków narodowych i innych państwowych obszarów chronionych na korzyści społeczne, psychologiczne i fizyczne związane $\mathrm{z}$ dobrostanem postrzegane przez odwiedzających. Okazało się, że wizyty w parkach poprawiają nastrój i poprawiają samopoczucie psychiczne w szczególności. Zostały one również postrzegane jako pomoc w wyleczeniu ze stresu. 


\section{Gromadzenie danych statystycznych}

Metsähallitus zbiera również informacje o liczbie odwiedzin najpopularniejszych państwowych obszarów chronionych i obszarów turystycznych znajdujących się pod jego administracją. W oparciu o gromadzenie danych ocenia się również wartość finansową wydatków odwiedzających na lokalną gospodarkę i zdrowie publiczne.

\subsection{Stany Zjednoczone Ameryki Północnej (USA) (por. Majdak 2014: 59-63 oraz tłumaczenia własne na podstawie: (Web-04, Web-05)}

Działania służące implementacji założeń rozwoju zrównoważonego na obszarach przyrodniczo cennych w USA są wynikiem zarówno złożonych programów (jak np. działania związane $\mathrm{z}$ dostosowaniem i modernizacją infrastruktury) jak i inicjatyw podejmowanych przy zaangażowaniu znacznie mniejszych środków (w tym np. działalność edukacyjna czy wydawnicza). Jednym z najważniejszych programów regulujących działania z zakresu rozwoju zrównoważonego pozostaje Green Parks Plan. Advancing Our Mission Through Sustainable Operations (tłum. Projekt Green Parks. Wspieranie naszej misji poprzez zrównoważone działania). Dokument został opublikowany w 2016 roku i ramowo określa cele i działania. Najważniejsze z nich przedstawia tabela 1 .

W ślad za powyższymi wskazaniami wymienić możemy szereg inicjatyw, które służą realizacji powyższych założeń. Wśród najważniejszych wymienić można następujące działania.

- Działalność informacyjna, działalność wydawnicza - prowadzenie punktów informacyjnych, udostępnianie bezpłatnych map, broszur, przewodników, działalność edukacyjna wolontariuszy przyczynia się do budowania świadomości turystów, służy poprawie bezpieczeństwa, ogranicza zachowania niepożądane.

- Działalność edukacyjna - realizacja rozbudowanych programów animacji i edukacji, organizacja wycieczek tematycznych, pokazów, spotkań, prelekcji. Oprócz funkcji edukacyjnej działalność ta ma także ważny aspekt praktyczny - zagospodarowuje i urozmaica czas turystom przebywającym w obrębie kempingów.

- Infrastruktura, miejsca noclegowe, punkty usługowo-handlowe - na terenie parków narodowych organizowane są specjalnie przygotowywane pola biwakowe, zlokalizowane w pobliżu szlaków. Są one wyposażone w odpowiednią infrastrukturę (m.in. wyposażone w „piaskownicę” do rozbicia namiotu, palenisko, metalową skrzynkę na żywność /ochrona przed niedźwiedziami/) i przystosowane do przyjęcia określonej liczby samochodów i namiotów. Do dyspozycji turyści mają także sklepy spożywcze (promujące ekologiczną i lokalną żywność), punkty serwisowe, zaplecze sanitarne i medyczne. Mimo na ogół dużej powierzchni takich pól (niekiedy są one przeznaczone dla nawet 300-400 samochodów - np. Grand Canyon, Zion, Yosemite National Park) w sezonie letnim niekiedy trudno znaleźć wolne miejsce, co świadczy o popularności tej formy wypoczynku.

- Lokalne stacje radiowe dla zmotoryzowanych - informują o aktualnych utrudnieniach, warunkach pogodowych, zagrożeniach.

- Ekologiczne autobusy (shuttle bus), alternatywne środki transportu (np. konie i muły), flota. Realizacja projektu przyczyniała się m.in. do poprawy bezpieczeństwa pieszych, redukcji emisji spalin, obniżenia poziomu hałasu. Przykład 30 shuttle busów wprowadzonych w Zion National Park pokazuje ponadto skalę skuteczności podobnych działań:

- system obsługuje w sezonie około 3 mln turystów,

- liczba samochodów prywatnych docierających do Kanionu Zion (najbardziej znany fragment parku) 


\section{Tabela 1. Cele strategiczne programu Green Parks Plan}

\begin{tabular}{lll}
\hline & Cele i działania (wersja oryginalna) & Cele i działania (tłumaczenie) \\
\hline 1. & Continuously Improve Environmental Performance. & Ciągłe poprawianie efektywności środowiskowej \\
& $\begin{array}{l}\text { The NPS will meet and exceed the requirements of all } \\
\text { applicable environmental laws and adopt sustainable } \\
\text { best practices in all facility operations. }\end{array}$ & NPS osiągnie wyznaczone normy środowiskowe oraz wdroży \\
\hline 2. & Be Climate Friendly and Climate Ready & Bądź przyjazny klimatowi i przygotuj się na zmiany klimatu \\
& $\begin{array}{l}\text { The NPS will reduce GHG emissions and adapt } \\
\text { facilities at risk from climate change. }\end{array}$ & NPS zmniejszy emisje gazów cieplarnianych i dostosuje \\
\hline 3. & Be Energy Smart & Bądź inteligentny energetycznie \\
& $\begin{array}{l}\text { The NPS will improve facility energy performance and } \\
\text { increase reliance on renewable energy. }\end{array}$ & NPS poprawi wydajność energetyczną obiektów i zwiększy \\
\hline 4. & Be Water Wise & zależność od energii odnawialnej. \\
& The NPS will improve facility water use efficiency. & NPS poprawi efektywność zużycia wody. \\
\hline 5. & Green Our Rides & Zielony transport
\end{tabular}

The NPS will transform our fleet and adopt greener

NPS zmieni naszą flotę, pojawią się bardziej ekologiczne transportation methods. metody transportu.

6. Buy Green and Reduce, Reuse, and Recycle Kupuj produkty naturalne, zmniejszaj, używaj ponownie i odzyskuj

The NPS will purchase environmentally friendly NPS kupi przyjazne dla środowiska produkty i zwiększy ilość products and increase waste diversion and recycling. odpadów do recyklingu.

7. Strengthen Sustainability Partnerships Wzmocnienie partnerstwa na rzecz zrównoważonego rozwoju

The NPS will incorporate sustainability initiatives into new and existing partnerships.

NPS włączą inicjatywy zrównoważonego rozwoju do nowe i istniejące partnerstwa.

8. Preserve Outdoor Experiences, Promuj zdrową aktywność na świeżym powietrzu Promote Healthy Engagement

The NPS will promote healthy outdoor experiences NPS będzie promować zdrową aktywność na świeżym and minimize the impact of facility operations on the environment. powietrzu i minimalizować wpływ podejmowanych działań na środowisko.

9. Foster Sustainability Beyond Our Boundaries Promuj zrównoważony rozwój poza naszymi granicami

The NPS will engage visitors about sustainability and NPS zaangażuje osoby z zewnątrz w zrównoważony rozwój invite their participation. i zaprosi ich do wspótpracy.

10. Green Our Grounds Zielona Ziemia

The NPS will enhance the sustainability of our NPS podejmie działania na rzecz zrównoważonego rozwoju landscapes. naszych krajobrazów.

Źródło: Opracowanie własne na podstawie: Green Parks Plan. Advancing Our Mission Through Sustainable Operations (Web-04) 
została ograniczona o ok. 5000 pojazdów dziennie,

- emisja szkodliwego $\mathrm{CO}_{2}$ zredukowano o niemal 2,5 tony rocznie (Web-02).

W wielu parkach trwa także wymiana floty na pojazdy hybrydowe i paliwooszczędne. Obecnie około 19\% samochodów i ciężarówek używanych do pracy w Yellowstone to pojazdy hybrydowe. Yellowstone pracuje także nad edukacją pracowników i odwiedzających na temat oszczędnego zużycia paliwa podczas jazdy i konserwacji (Web-o4).

Alternatywę dla wymienionych wyżej środków transportu (a także dodatkową atrakcję turystyczną) stanowi możliwość zwiedzania parków w towarzystwie kwalifikowanych przewodników i na odpowiednio przygotowanych zwierzętach (koniach i mułach).

\section{Energia odnawialna}

W niektórych parkach narodowych działają programy mające na celu wdrożenie urządzeń umożlwiających pozyskiwanie energii ze źródeł odnawialnych. Wśród miejsc, które odniosły sukces wymienić można chociażby Bechler, w którym system paneli ogniw słonecznych spełnia 90\% potrzeb elektrycznych w sezonie letnim oraz Lamar Buffalo Ranch, w którym podobny system zaspokaja 100\% zapotrzebowania na energię elektryczną i wykorzystuje akumulatory hybrydowe do gromadzenia energii (Web-04)

\section{Ekologiczna administracja}

Administracja oraz poszczególne jednostki parków narodowych w swojej działalności wykorzystują produkty ekologiczne, $\mathrm{tj}$.

- Posiadające minimalne opakowanie,

- Biodegradowalne lub nadające się do recyklingu,

- Bez toksycznych składników,

- Wymagające minimalnej energii do produkcji i transportu,

- Zawierające produkty z recyklingu (np. papier biurowy z 30\% zawartością makulatury czy papierowe ręczniki wykonane w 100\% z makulatury).
- Zmniejsza się również zakup przedmiotów plastikowych jednorazowego użytku.

Limitowanie wejść i opłaty

Warto zaznaczyć, że wstęp do niektórych, szczególnie wrażliwych fragmentów parku jest limitowany przez system zezwoleń i przepustek (niekiedy udostępnianych w drodze losowania) oraz opłat.

\section{Konkluzja}

Krystalizująca się od lat 6o. XX w. koncepcja rozwoju zrównoważonego, stanowiła jeden z najsilniejszych impulsów dla zerwania z dominującą wówczas turystyką masową, wraz ze wszystkimi negatywnymi zjawiskami, jakie ze sobą niosła. Nadmierna eksploatacja środowiska naturalnego, szkodliwy wpływ na życie społeczno-kulturowe obszarów recepcyjnych, niepożądane działania w sferze gospodarczej zastąpić miały działania służące m.in. minimalizacji ingerencji w środowisko przyrodnicze, poszanowaniu odmienności kulturowej, zwiększaniu udziału ludności miejscowej w usługach turystycznych, wzrostowi satysfakcji i zadowolenia z turystyki (Coccossis, Parpairis 2000: 107-125, Gołembski 2002: 368-384).

Jak widać postulaty formułowane blisko siedemdziesiąt lat temu nie straciły na aktualności, a założenia rozwoju zrównoważonego nadal stanowią ważny punkt odniesienia oraz źródło cennych inspiracji dla działań praktycznych. W tym kontekście na uwagę zasługują zarówno działania będące rezultatem rozbudowanych, ogólnokrajowych projektów, jak i inicjatyw realizowanych na poziomie lokalnym.

\section{Uwaga}

Artykuł prezentuje dane uzyskane m.in. w ramach projektu badawczego Rozwój zrównoważony i innowacje $w$ turystyce, realizowanego w Akademii Wychowania Fizycznego w Warszawie (projekt o symbolu DM-59). 


\section{Bibliografia}

Coccossis H., Parpairis A. 200o, Assessing the interaction between heritage, environment and tourism: Mykonos [in:] Sustainable tourism development, Coccossis H., Nijkamp P. (red.), Aldershot-Burlington-Singapore-Sydney, ss. 107-125.

Gołembski G., 2002, Pojęcie i cele zintegrowanego zarzadzania w regionach [w:] Kompendium wiedzy o turystyce Gotembski G. (red.), wyd. PWN, Warszawa ss. 368-384.

Jalinik M., 2009, Zarządzanie gospodarstwem ekoagroturystycznym na obszarach przyrodniczo cennych: Zeszyty Naukowe Politechniki Białostockiej. Ekonomia i Zarządzanie. Zeszyt 14, Białystok, ss. 85-94.

Kassenberg A., 2007, Zrównoważony rozwój a koncepcja przestrzennego zagospodarowania kraju [w:] Gorzelak G., Tucholska A. (red.), Rozwój, region, przestrzeń, Ministerstwo Rozwoju Regionalnego, Warszawa, s. 53-87.

Kowalczyk A., (red.), 2010, Turystyka zrównoważona, wyd. PWN, Warszawa.
Majdak P., 2014, Sustainable Tourism in the Selected US National Parks. Practical Solutions, [w:] Guszkowska M. (red. nacz.), Turystyka i Rekreacja, tom II/2014 nr 2, wyd. AWF, Warszawa, ss. 59-63.

(Web-1) Principles of Sustainable Tourism, http:// www.metsa.fi/web/en/sustainablenaturetourism, dostęp: 13.11.2017.

(Web-2) Zion National Parks: Tourist public transport http://www.nps.gov/dsc/d_publications/d_1_ gpsd_1_ch1.htm, dostęp 5.05.2014.

(Web-3) Sustainable nature tourism, dostęp: 20.12.2017.

(Web-4) Green Parks Plan, https://www.nps.gov/ subjects/sustainability/upload/NPS-Green-Parks-Plan-2016.pdf, dostęp: 20.12.2017.

(Web-5) Conservation measures, https://www.nps. gov/yell/getinvolved/energyconservation.htm, dostęp: 20.12.2017.

\section{Sustainable tourism in the valuable natural areas. Theoretical contexts - strategies - implementation}

\section{Abstract}

The considerations presented in the article focus on issues related to the implementation of the assumptions of the concept of sustainable development in relation to valuable natural areas that perform tourist functions.

The research interests focused on Finland and the United States of America. Due to the large diversity resulting from natural, geographical, spatial and organizational or political conditions - the presented catalog of practical solutions contains a comprehensive set of initiatives that implement in practice the assumptions of sustainable development. These include both activities resulting from the implementation of nationwide projects as well as initiatives implemented at the level of local associations.

The presented solutions show that the assumptions of sustainable development are a source of valuable inspiration for practical activities, and the concept itself is not limited only to the discursive and theoretical aspects.

\section{Keywords}

sustainable tourism, valuable natural areas 